\title{
Speculative petroleum systems of the Punta del Este Basin (offshore Uruguay)
}

\author{
Sistemas petrolíferos especulativos da \\ bacia de Punta del Este (offshore Uruguai)
}

\author{
Ethel Morales ${ }^{1 *}$, Hung Kiang Chang ${ }^{2}$, Matías Soto ${ }^{1}$, Gerardo Veroslavsky ${ }^{1}$, \\ Bruno Conti ${ }^{3}$, Héctor de Santa $\mathrm{Ana}^{3}$, Fernando Santos Corrêa ${ }^{2}$
}

\begin{abstract}
The Uruguayan continental margin was generated as the result of the breakup of Gondwana and, later, the opening of the South Atlantic Ocean, which began in the Jurassic. Three major areas of Meso-Cenozoic sedimentation are located in the Uruguayan offshore: the Punta del Este Basin, the southernmost sector of the Pelotas Basin and the Oriental del Plata Basin. These basins share the classical stages of tectono-sedimentary evolution of the other Atlantic basins, including the prerift (Paleozoic), rift (Jurassic-Early Cretaceous), transition (Barremian-Aptian) and postrift (Aptian-present) phases. Based on the analysis of basin evolution through seismic sections and well data as well as on the establishment of analogies with productive Atlantic basins, four speculative petroleum systems are proposed for the Punta del Este Basin: 1) Marine petroleum system of the prerift stage: Devonian/Permian-Devonian/Permian(?), 2) Lacustrine petroleum system of the synrift stage: Neocomian-Neocomian(?), 3) Marine petroleum system of the Cretaceous postrift: Aptian-Late Cretaceous(?), 4) Marine petroleum system of the Cenozoic postrift: Paleocene-Paleogene/Neogene(?).
\end{abstract}

KEYWORDS: petroleum system; tectono-stratigraphic evolution; offshore Uruguay.
RESUMO: A margem continental uruguaia é resultado da fragmentação do supercontinente Gondwana e posterior abertura do Oceano Atlântico, iniciados no Jurássico. Três bacias sedimentares estão presentes na margem continental do Uruguai: a Bacia de Punta del Este, a porção mais austral da Bacia de Pelotas e a Bacia Oriental del Plata. As bacias da margem continental do Uruguai compartilham os clássicos estágios tectono-sedimentares evolutivos das demais bacias marginais atlanticas, incluindo as fases pré-rifte (Paleozoico), rifte (Jurássico-Cretáceo Inferior), transiçáa (Barremiano-Aptiano) e pós-rifte (Aptiano-Presente). Quatro sistemas petroliferos especulativos foram definidos para a Bacia Punta del Este, baseados na análise de seçóes sísmicas e dados de poços e no estabelecimento de analogias com as bacias marginais atlanticas productoras de hidrocarbonetos: 1) sistema petrolifero marinho da fase pré-rifte: Devoniano/Permiano-Devoniano/Permiano(?), 2) sistema petrolifero lacustre da fase rifte: Neocomiano/Neocomiano(?), 3) sistema petrolifero marinho da fase pós-rifte cretácea: Aptiano-Cretáceo Superior(?), 4) sistema petrolifero marinho da fase pós-rifte cenozoica: Paleoceno-Paleogeno/Neogeno(?),

PALAVRAS-CHAVE: sistemas petroliferos; evolução tectono-sedimentar; margem continental do Uruguai.

\footnotetext{
${ }^{1}$ Instituto de Ciencias Geológicas, Facultad de Ciencias, Iguá, Montevideo, Uruguay. E-mails: ethel@fcien.edu.uy, msoto@fcien.edu.uy, gerardo@fcien.edu.uy 2Instituto de Geociências e Ciências Exatas, Universidade Estadual Paulista, Rio Claro (SP), Brazil. E-mails: chang@rc.unesp.br,fer.s.correa@gmail.com ${ }^{3}$ Exploración y Producción, Administración Nacional de Combustiles, Alcoholes y Portland - ANCAP, Montevideo, Uruguay. E-mails: bconti@ancap.com.uy. hdesantaana@ancap.com.uy

*Corresponding author.

Manuscript ID: 20170078. Received in: 06/12/2017. Approved in: 08/21/2017.
} 


\section{INTRODUCTION}

The Uruguayan continental margin is a typical volcanic rifted margin, segmented by the Río de la Plata Transfer System (RPTS; Soto et al. 2011). Three basins are identified: the Punta del Este Basin, the southernmost portion of the Pelotas Basin and the ill-defined Oriental del Plata Basin (Stoakes et al. 1991, Ucha et al. 2004, Soto et al. 2011, Conti et al. 2017, Morales et al. 2017) (Fig. 1).

The genesis of these basins was associated to the processes that led to the fragmentation of the Gondwana supercontinent and subsequent opening of the Atlantic Ocean, from the Jurassic onwards (Rabinowitz \& LaBrecque 1979, Gladczenko et al. 1997, Heine et al. 2013).

Particularly, the Punta del Este Basin is separated from the Salado Basin (offshore Argentina) to the southwest through the Plata High and the Salado Fracture Zone, and from the Pelotas Basin to the northeast through the Polonio
High and the RPTS (Stoakes et al. 1991, Ucha et al. 2004, Raggio et al. 2011, Soto et al. 2011, Morales et al. 2017).

From an exploratory point of view, only two boreholes have been drilled in the Punta del Este Basin: the Lobo and Gaviotín wells (Chevron Oil Uruguay 1976). Both were declared dry wells, but it should be taken into account that they were drilled in graben shoulders in the proximal sector of the basin, in the continental shelf. Hence, they are neither representative of the basin infill (far thicker seawards) nor of the petroleum systems. In fact, the distal, still undrilled sector shows a good development of depositional systems, including marine ones, and therefore a higher petroleum potential.

\section{GEOLOGICAL SETTING}

The Western Gondwana breakup was related to the implantation of a rift system, which evolved into a passive

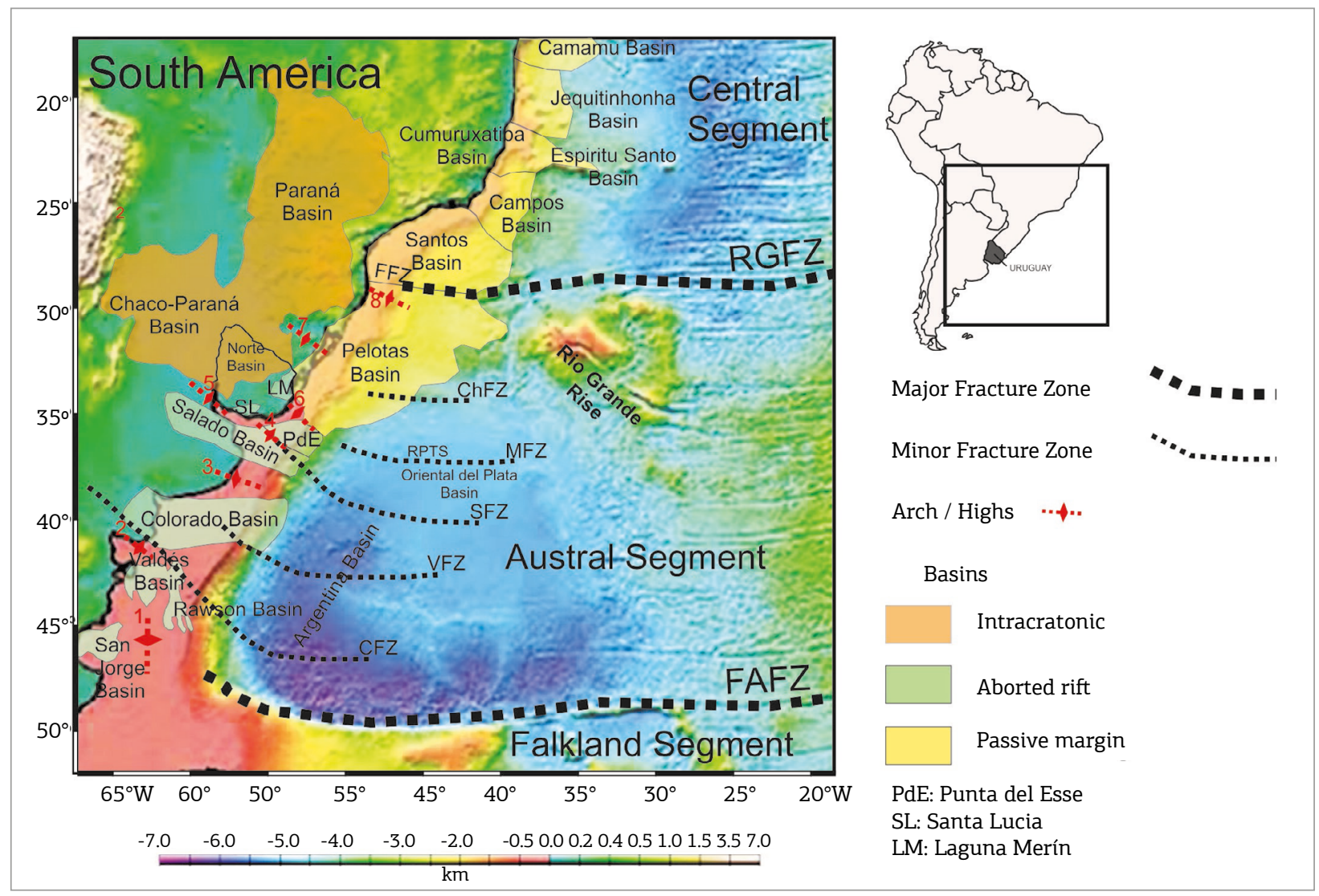

Figure 1. Topographical-bathymetric map of South America overlain by selected offshore and onshore basins and structural elements. Inset shows the location of the figure in relation to South America, with Uruguay highlighted in black. Based on Moulin et al. (2005), Franke et al. (2007) and Soto et al. (2011). Seafloor topography based on Becker et al. (2009). Major Fracture Zones: FAFZ, Falkland-Agulhas Fracture Zone; RGFZ, Rio Grande Fracture Zone. Minor Fracture Zones: CFZ, Colorado Fracture Zone; VFZ, Ventana Fracture Zone; SFA, Salado Fracture Zone; RPTS, Rio de la Plata Transfer System/Meteor Fracture Zone; MFZ, Meteor Fracture Zone; ChFZ, Chui Fracture Zone; FFZ, Florianópolis Fracture Zone. Arch/Highs: 1: Patagonia Oriental; 2: Río Negro; 3: Tandilia; 4: Plata; 5: Martín García; 6: Polonio; 7: Rio Grande; 8: Florianópolis. Modified from Morales et al. (2017). 
margin stage, either non-volcanic (northern and central segments) or volcanic (south of Santos basin; Moulin et al. 2005, Blaich et al. 2009).

In the volcanic rifted margin of the Southwestern Atlantic (offshore of Argentina and Uruguay) a group of aborted rift structures, oriented perpendicularly to the margin, developed (San Jorge, Valdés, Rawson, Colorado, Salado and Punta del Este basins). The northernmost of these rift structures is the Punta del Este Basin (Fig. 1).

From a general point of view, four models for the genesis of these rift structures have been proposed:

- the classical triple joint model as a consequence of a thermal anomaly (Introcaso \& Ramos 1984, Stoakes et al. 1991);

- stress accommodation through rotation of the South American plate in relation to the African plate, as a result of crustal stretching north of the Walvis-Río Grande Rise and oceanic expansion to the south (Chang et al. 1992);

oblique extension at the beginning of Atlantic Ocean expansion (MacDonald et al. 2003); and

variations in strain orientation and stretching velocity (Heine et al. 2013).

All these models share the importance of the basement inheritance, the structures of which conditioned rift development. These structures were generated as a result of the suturing processes in Western Gondwana, which occurred at the end of the Proterozoic (Tankard et al. 1995, Pángaro \& Ramos 2012, Heine et al. 2013).

Offshore Argentina, these rift structures are bounded to the East by a conspicuous basement high, which marks the start of the Argentine Basin, placed entirely in ultradeep waters (Raggio et al. 2011, Figueroa et al. 2005, Urien 2001). This high precluded marine deposition in the Salado and Colorado basins offshore Argentina until the MaastrichtianPaleocene. This high becomes subtler to the NE, being almost absent in the southern portion of the continental margin of Uruguay (i.e., the Punta del Este Basin). Hence, the early postrift sedimentation in the Punta del Este Basin shows a different depositional architecture from the Colorado and Salado basins, which contradicts the homogeneous characteristics that historically have been assigned to them (Tavella \& Wright 1996).

Onshore Uruguay, the Santa Lucía and Laguna Merín basins are part of a NE-trending structural lineament called Santa Lucía-Aiguá-Merín (SaLAM; Rossello et al. 2000, 2007), which has been interpreted as an aborted rift (Veroslavsky et al. 2007). This lineament involved a first extensional stage, which started in the Jurassic, and a second dextral transcurrent stage during the Aptian-Albian.

\section{TECTONIC AND STRATIGRAPHIC EVOLUTION OF THE PUNTA DEL ESTE BASIN}

The tectonic and stratigraphic evolution of the Punta del Este Basin comprise four stages, each of which is characterized by a particular stratigraphic architecture and structural configuration. These stages are:

prerift;

- synrift;

transition; and

- postrift (Morales 2013, Morales et al. 2017, Conti et al. 2017) (Fig. 2).

Prerift stage (Paleozoic) includes at least Permian sedimentary rocks (drilled by the Gaviotín well) correlated with units of the regional Paleozoic basins, which were preserved as relics after the general uplift and denudation caused by the Late Hercynian Orogeny (Milani \& Thomas Filho 2000, Holz et al. 2010, Pángaro et al. 2015).

Synrift stage (Jurassic-Early Cretaceous) is characterized by normal faults, either NW-SE trending in proximal sectors of the basin (initial rift stage) or E-W/NE-SW in the distal sectors (late rift phase). The infill comprises both volcanic and sedimentary rocks, as proven in the Gaviotín and Lobo wells.

Transitional stage (Barremian-Aptian) corresponds to the initial phase of thermal subsidence of the basin. It develops on a continental crust substrate and shows sag geometry, thinning towards the structural highs (Polonio and Plata highs). This stage marks the end of the tectonic activity of the main faults of the synrift stage. Also during this stage, graben shoulders are surpassed by the sedimentation for the first time since the Jurassic.

Postrift stage (Aptian-Recent) is characterized by a sedimentary wedge, which becomes thicker seawards. It is the result of the interaction among sedimentary supply, subsidence rate and base level changes. This stage is represented by eleven depositional sequences (Morales et al. 2017), grouped in two megasequences: Cretaceous postrift and Cenozoic postrift. In the Punta del Este Basin, the former megasequence constitutes the largest Cretaceous depocenter of the entire continental margin of Uruguay. It starts with a transgressive system tract (TST), and then shows general regressive features, developing thick sedimentary successions with regressive architecture. The Cenozoic postrift megasequence, subsequently, showed general transgressive features, with a landward coastline migration, although several of the depositional sequences show regressive characteristics. 


\section{METHODOLOGY}

In order to perform this analysis, 2D reflection seismic sections, as well as geophysical, lithological and paleontological data of the Lobo and Gaviotín wells, were used (Fig. 3). In the analysis of the seismic data, for the interpretation of depositional sequences, system tracts and the distribution of petroleum system components, the methodology commonly used in sequence stratigraphy was utilized (for a recent review, please refer too Catuneanu 2006).

Maturation history of the potential source rocks of the Punta del Este Basin was studied through modeling of three hypothetical wells along a representative dip seismic line (Figs. 2 and 3).

For each well, its stratigraphy was defined on the basis of the stratigraphic analysis developed by Morales et al. (2017). For each depositional sequence, the relative abundance of lithologies was estimated (Tabs. 1, 2 and 3). The referred ages correspond to the age, in $\mathrm{Ma}$, of the top of each sequence.

For the speculative petroleum systems defined herein, four potential source rocks were considered: one in the prerift stage, one in the synrift stage, and the remaining two in the postrift stage: marine Permian source rock;

lacustrine Neocomian source rock;

marine Aptian source rock; and

marine Paleocene source rock.

The geochemical features of these potential source rocks were chosen taking into account the data published for the South Atlantic basins and the onshore basins of Uruguay (Tab. 4). In all cases, the lowest TOC value cited in the literature was considered.

For thermal calibration, vitrinite reflectance values measured in the Lobo and Gaviotin Wells by Chevron Oil Uruguay (1976) were used (Tab. 5). A constant thermal flux was considered, equal to the mean global thermal flux (60 mW/m2; Pollack et al. 1993).

\section{RESULTS}

Four speculative petroleum systems (Magoon \& Dow 1994) are proposed for the Punta del Este Basin:

marine petroleum system of the prerift stage;

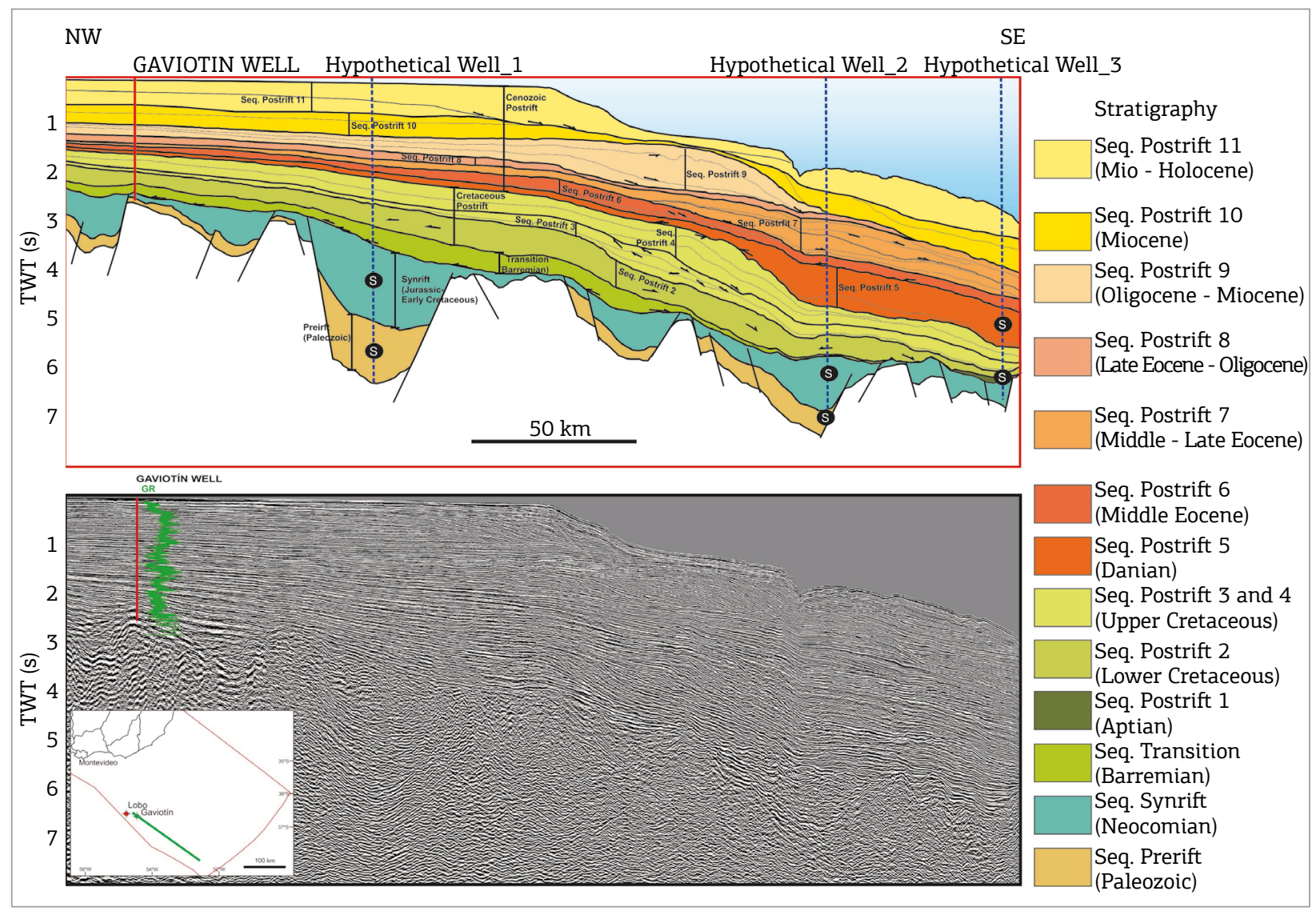

Figure 2. Dip seismic section (below) and interpreted geoseismic sections (above) of the Punta del Este Basin, depicting the sequences identified in Morales et al. (2017) and the location of hypotetical wells. S in black circle: potential source rocks. Seismic profile courtesy of ANCAP. 
lacustrine petroleum system of the synrift stage;

marine petroleum system of the Cretaceous postrift; and marine petroleum system of the Cenozoic postrift.

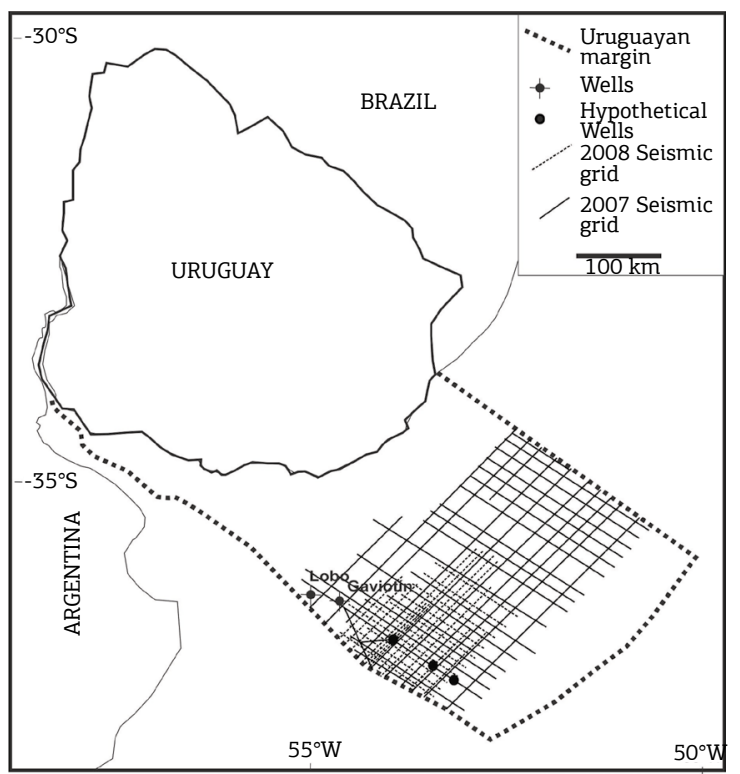

Figure 3. Location of the Lobo and Gaviotín wells, 2D seismic surveys from the database used in this contribution and locations of the hypothetical wells modelled.
Figure 4 presents the burial diagrams for the three hypothetical wells. It is considered an immature zone until Ro $=0.6 \%$, oil zone between $0.6>$ Ro $<1 \%$, peak oil generation between $1>$ Ro $<1.3 \%$, wet and condensed gas zone between $1.3>$ Ro $<2 \%$ and dry gas zone when Ro> 2\%.

The speculative petroleum systems proposed herein for the Punta del Este Basin are described below.

\section{Marine petroleum system of the prerift stage: Devonian/Permian-Devonian/ Permian(?)}

This petroleum system is related to the prerift deposits, partially drilled in the Gaviotín well, about 1,500 m thick, according to seismic data. It is apparently restricted to the proximal sector of the basin.

Source rocks are expected to be present by correlation with the Norte/Paraná Basin of Uruguay/ Brazil and other regional Paleozoic basins, such as the Hespérides Basin (Pángaro et al. 2015). The former basin includes Early Devonian and Early Permian source rocks with high TOC values (de Santa Ana \& Ucha 1994, Campos et al. 1998, Milani \& Zalán 1999, Milani et al. 2000, de Santa Ana 2000, Pángaro et al. 2015), reaching in Uruguay 3,6\% (Cordobés Formation; de Santa Ana \& Ucha

Table 1. Stratigraphy and lithologies proposed for hypothetical well 1.

\begin{tabular}{|c|c|c|c|c|c|c|c|}
\hline \multirow{2}{*}{ Sequence } & \multirow{2}{*}{$\begin{array}{l}\text { Age } \\
\text { (Ma) }\end{array}$} & \multirow{2}{*}{ Age } & \multirow{2}{*}{$\begin{array}{c}\text { Thickness } \\
\text { (m) }\end{array}$} & \multicolumn{4}{|c|}{ Lithology } \\
\hline & & & & Sandstone & Silstone & Shale & Igneous \\
\hline Postrift 11 & 0 & Mio-Holocene & 792 & 45 & 35 & 20 & \\
\hline Postrift 10 & 13 & Miocene & 335 & 20 & 35 & 45 & \\
\hline Postrift 9 & 20 & Oligocene-Miocene & 518 & 30 & 30 & 40 & \\
\hline Postrift 8 & 31 & Late Eocene-Oligocene & 396 & 20 & 35 & 45 & \\
\hline Postrift 7 & 37 & Late Eocene & 183 & 35 & 35 & 30 & \\
\hline Postrift 6 & 45 & Middle Eocene & 30 & 30 & 35 & 35 & \\
\hline Postrift 5 & 61 & Paleocene & 244 & 20 & 35 & 45 & \\
\hline Postrift 4 & 66 & Upper Cretaceous & 884 & 35 & 35 & 30 & \\
\hline Postrift 3 & 85 & Upper Cretaceous & 235 & 35 & 35 & 30 & \\
\hline Postrift 2 & 100 & Lower Cretaceous & 549 & 35 & 35 & 30 & \\
\hline Postrift 1 & 113 & Aptian & & & lot deposite & & \\
\hline Transition & 125 & Barremian & 1128 & 25 & 35 & 35 & 5 \\
\hline Synrift & 136 & Neocomian & 3176 & 45 & 10 & 35 & 10 \\
\hline Prerift & 251 & Paleozoic & 1250 & 45 & 20 & 35 & \\
\hline
\end{tabular}


Table 2. Stratigraphy and lithologies proposed for hypothetical well 2.

\begin{tabular}{|c|c|c|c|c|c|c|c|}
\hline \multirow{2}{*}{ Sequence } & \multirow{2}{*}{$\begin{array}{l}\text { Age } \\
\text { (Ma) }\end{array}$} & \multirow{2}{*}{ Age } & \multirow{2}{*}{$\begin{array}{l}\text { Thickness } \\
\text { (m) }\end{array}$} & \multicolumn{4}{|c|}{ Lithology } \\
\hline & & & & Sandstone & Silstone & Shale & Igneous \\
\hline Postrift 11 & 0 & Mio-Holocene & 300 & 10 & 30 & 60 & \\
\hline Postrift 10 & 13 & Miocene & 400 & 45 & 20 & 35 & \\
\hline Postrift 9 & 20 & Oligocene-Miocene & \multicolumn{5}{|c|}{ Eroded } \\
\hline Postrift 8 & 31 & Late Eocene-Oligocene & 200 & 10 & 35 & 55 & \\
\hline Postrift 7 & 37 & Late Eocene & 600 & 35 & 30 & 35 & \\
\hline Postrift 6 & 45 & Middle Eocene & 200 & 15 & 25 & 60 & \\
\hline Postrift 5 & 61 & Paleocene & 1050 & 15 & 35 & 50 & \\
\hline Postrift 4 & 66 & Upper Cretaceous & 800 & 45 & 35 & 20 & \\
\hline Postrift 3 & 85 & Upper Cretaceous & 300 & 30 & 30 & 40 & \\
\hline Postrift 2 & 100 & Lower Cretaceous & 550 & 35 & 35 & 30 & \\
\hline Postrift 1 & 113 & Aptian & \multicolumn{5}{|c|}{ Not deposited } \\
\hline Transition & 125 & Barremian & \multicolumn{5}{|c|}{ Eroded } \\
\hline Synrift & 136 & Neocomian & 1700 & 45 & 10 & 35 & 10 \\
\hline Prerift & 251 & Paleozoic & 550 & 45 & 20 & 35 & \\
\hline
\end{tabular}

Table 3. Stratigraphy and lithologies proposed for hypothetical well 3.

\begin{tabular}{|c|c|c|c|c|c|c|c|}
\hline \multirow{2}{*}{ Sequence } & \multirow{2}{*}{$\begin{array}{l}\text { Age } \\
(\mathrm{Ma})\end{array}$} & \multirow{2}{*}{ Age } & \multirow{2}{*}{$\begin{array}{c}\text { Thickness } \\
\text { (m) }\end{array}$} & \multicolumn{4}{|c|}{ Lithology } \\
\hline & & & & Sandstone & Silstone & Shale & Igneous \\
\hline Postrift 11 & 0 & Mio-Holocene & 335 & 10 & 30 & 60 & \\
\hline Postrift 10 & 13 & Miocene & 533 & 25 & 35 & 40 & \\
\hline Postrift 9 & 20 & Oligocene-Miocene & \multicolumn{5}{|c|}{ Eroded } \\
\hline Postrift 8 & 31 & Late Eocene-Oligocene & \multicolumn{5}{|c|}{ Eroded } \\
\hline Postrift 7 & 37 & Late Eocene & 877 & 20 & 35 & 45 & \\
\hline Postrift 6 & 45 & Middle Eocene & 555 & 20 & 35 & 45 & \\
\hline Postrift 5 & 61 & Paleocene & 1143 & 15 & 35 & 50 & \\
\hline Postrift 4 & 66 & Upper Cretaceous & 762 & 45 & 35 & 20 & \\
\hline Postrift 3 & 85 & Upper Cretaceous & 762 & 25 & 35 & 40 & \\
\hline Postrift 2 & 100 & Lower Cretaceous & 389 & 35 & 35 & 30 & \\
\hline Postrift 1 & 113 & Aptian & 180 & 10 & 15 & 75 & \\
\hline Transition & 125 & Barremian & \multicolumn{5}{|c|}{ Eroded } \\
\hline Synrift & 136 & Neocomian & 800 & 45 & 15 & 30 & 10 \\
\hline Prerift & 251 & Paleozoic & \multicolumn{5}{|c|}{ Absent } \\
\hline
\end{tabular}


1994) and 13,5\% (Mangrullo Formation; de Santa Ana 2000). In particular, the latter unit comprises Type I, oil-prone kerogen.

Table 4. Geochemical data for potential source rocks used in the burial model.

\begin{tabular}{l|c|c|c}
\hline \multicolumn{4}{c}{ Potential source rocks } \\
\hline Stage & Age & OM type & TOC (\%) \\
\hline Prerift & Permian & I & 8 \\
\hline Synrift & Neocomian & I & 3 \\
\hline Cretaceous postrift & Aptian & I & 5 \\
\hline Cenozoic postrift & Paleocene & II & 1.9 \\
\hline
\end{tabular}

Table 5. Vitrinite reflectance for Lobo and Gaviotín wells (Chevron Oil Uruguay 1976).

\begin{tabular}{l|c|l|c}
\hline \multicolumn{2}{c|}{ Lobo } & \multicolumn{2}{c}{ Gaviotín } \\
\hline \multicolumn{1}{c|}{ Ro (\%) } & Depth (m) & \multicolumn{1}{c}{ Ro (\%) } & Depth (m) \\
\hline 0,25 & 300 & 0,32 & 650 \\
\hline 0,4 & 600 & 0,41 & 1300 \\
\hline 0,45 & 800 & 0,45 & 1700 \\
\hline 0,55 & 1000 & 0,80 & 3300 \\
\hline 0,7 & 1550 & 0,80 & 3600 \\
\hline 0,75 & 1700 & - & - \\
\hline 0,85 & 2100 & - & - \\
\hline
\end{tabular}

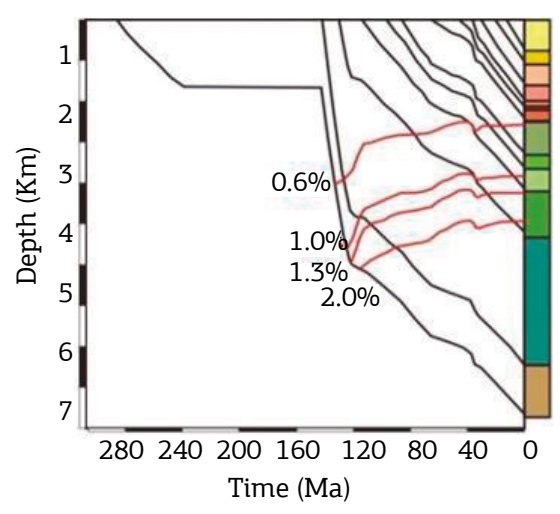

\begin{tabular}{c|c|c|c|c}
\hline \multicolumn{5}{c}{ Hypothetical well-1 } \\
\hline $\begin{array}{c}\text { Source } \\
\text { rock }\end{array}$ & Oil & $\begin{array}{c}\text { Oil } \\
\text { peak }\end{array}$ & $\begin{array}{c}\text { Wet gas / } \\
\text { condensate }\end{array}$ & Dry gas \\
\hline Prerift & 132 & 123 & 120 & 119.5 \\
\hline Rift & 126 & 113 & 106 & 88 \\
\hline
\end{tabular}

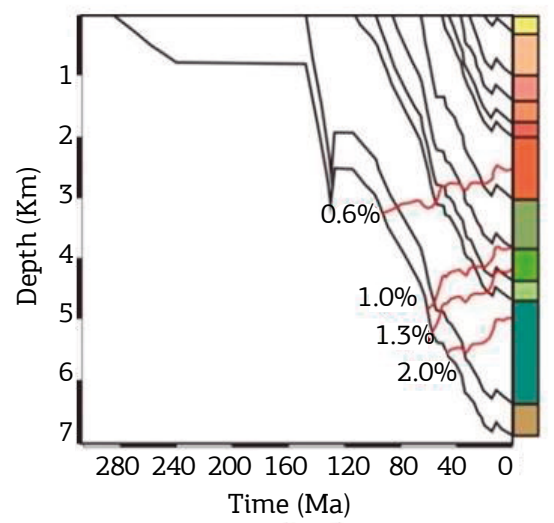

\begin{tabular}{c|c|c|c|c}
\hline \multicolumn{5}{c}{ Hypothetical well-2 } \\
\hline $\begin{array}{c}\text { Source } \\
\text { rock }\end{array}$ & Oil & $\begin{array}{c}\text { Oil } \\
\text { peak }\end{array}$ & $\begin{array}{c}\text { Wet gas / } \\
\text { condensate }\end{array}$ & Dry gas \\
\hline Prerift & 94 & 63 & 58 & 49 \\
\hline Rift & 81 & 57 & 50 & 35 \\
\hline
\end{tabular}

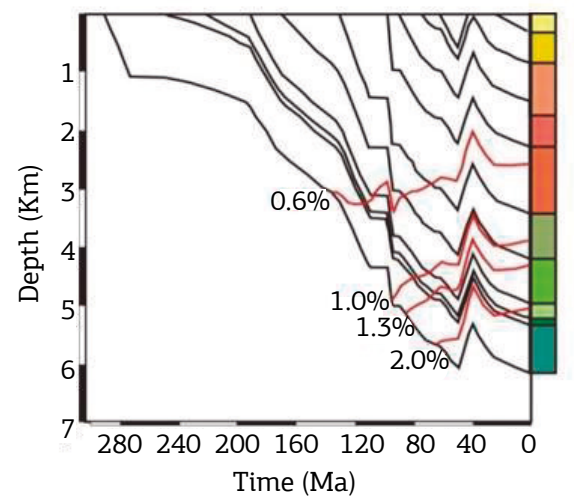

\begin{tabular}{c|c|c|c|c}
\hline \multicolumn{5}{c}{ Hypothetical well-3 } \\
\hline $\begin{array}{c}\text { Source } \\
\text { rock }\end{array}$ & Oil & $\begin{array}{c}\text { Oil } \\
\text { peak }\end{array}$ & $\begin{array}{c}\text { Wet gas / } \\
\text { condensate }\end{array}$ & Dry gas \\
\hline Aptian & 58 & 41 & 35 & 10 \\
\hline Paleocene & 54 & 35 & 28 & \\
\hline
\end{tabular}

Figure 4. Burial diagrams for the three hypothetical wells. 
Reservoir rocks may include fluvio-deltaic and aeolian sandstones, equivalent to the Early Permian Tres Islas Formation and Late Permian Buena Vista Formation of the Norte Basin (Veroslavsky et al. 2003).

Seal rocks may be represented by Permian marine shales, as well as Mesozoic lacustrine shales and basalts of the synrift sequence. Traps would be mainly of structural or combination type, including tilted blocks of the prerift sequence, preserved as relics bounded by unconformities.

Hydrocarbon migration would have been lateral and short vertical along prerift sandstones, and subordinately along faults in stretched crust sectors, involving prerift and synrift sequences.

Transformation of organic matter of Paleozoic source, rocks would have occurred entirely by the Cretaceous in the deepest depocenters. In shallower deposits, peak oil generation would have been reached in the early Paleogene, and wet gas/condensate window, in the late Paleogene. Nowadays, this source rock is inferred to be senile.

This petroleum system has the advantage of high-quality potential source rocks, and Mesozoic-Cenozoic overburden is thick enough to ensure thermal maturation. Main disadvantages are the low preservation potential of Paleozoic relics and the reduced porosity and permeability values expected due to the high depths reached by the reservoirs.

This speculative petroleum system is summarized in Figure 5.

\section{Lacustrine petroleum system of the synrift stage: Neocomian-Neocomian(?)}

Rift sequence in the Punta del Este basins is represented by a series of conspicuous hemigrabens, with an estimated thickness of up to 3,000 $\mathrm{m}$ according to seismic data. Although none of the hemigrabens have been drilled so far, the presence of lacustrine depositional systems with organic-rich shales is expected due to geological modeling and analogies with both onshore Uruguay and basins from the South Atlantic continental margin.
Lacustrine shales with up to $10 \%$ generated the oil responsible for most of hydrocarbon commercial accumulations in South Atlantic basins (Mello et al. 1994, Hartwing et al. 2012, Mello et al. 2012), as well as non-commercial accumulations (e.g. AJ-1 well in Orange Basin; Jungslager 1999). Furthermore, in the Santa Lucía Basin (the onshore equivalent of the Punta del Este Basin), the lacustrine shales of the Castellanos Formation show TOC values up to 2,95\% (ANCAP, 1994).

Main reservoir rocks include alluvial conglomerates and sandstones related to basin edges, lacustrine fans, and fluvial and deltaic depositional systems of the synrift stage. Some of these lithologies crop out in the Santa Lucía Basin (Mígues and Cañada Solís Formations; de Santa Ana \& Ucha 1994, Rossello et al. 2000). Secondary reservoirs may include shelfal sandstones and basin floor fans of the overlying Cretaceous postrift sequence.

Seal rocks include lacustrine shales and volcanic rocks of the synrift sequence. Traps would be diverse, including stratigraphic (e.g. alluvial fans and lacustrine fans), combination (e.g. truncations related to break-up unconformity, pinchouts against hemigraben shoulders) and structural traps (e.g. tilted blocks).

Hydrocarbon migration among synrift facies would have been vertical and lateral along the abundant faults of this sequence. Cretaceous postrift reservoirs may have been charged through longer vertical migration along reactivated faults.

Transformation of organic matter of Cretaceous source rocks would have occurred entirely by the Cretaceous in the deepest depocenters. In less thick hemigrabens, oil generation peak would have been reached in the Paleocene/Eocene, and wet gas/condensate and dry gas windows by the end of the Eocene.

An advantage of this petroleum system is that it has been proven in several basins of the South Atlantic (Coward et al. 1999, Chang et al. 2008, Mello et al. 2012, Beglinger et al. 2012), and according to the geological model, its presence in the Punta del Este Basin is highly probable. However,

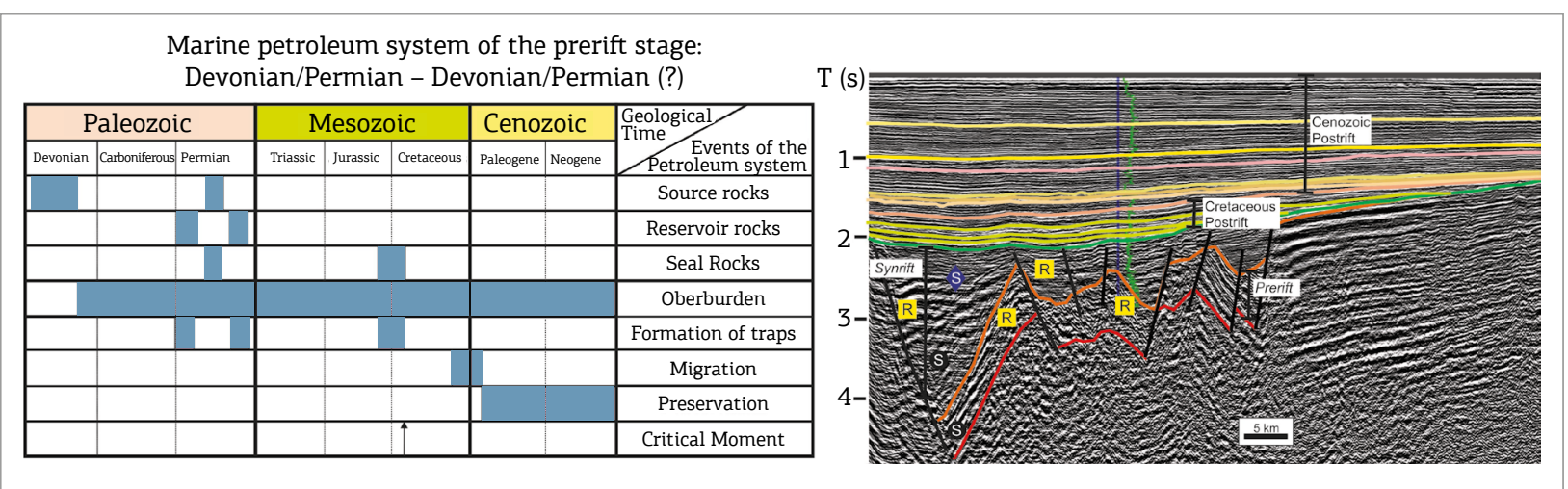

Figure 5. The marine petroleum system of the prerift stage: Devonian/Permian-Devonian/Permian(?), showing the chart of events and a representative seismic section. $S$ in black circle: potential source rocks. $S$ in blue rhombus: potential seal rocks. $R$ in yellow square: potential reservoir rocks. Seismic profile courtesy of ANCAP. 
reservoir depth is rather high $(>3,000 \mathrm{~m}$ rock depth). Moreover, hemigrabens are of rather small size.

This speculative petroleum system is summarized in Figure 6.

\section{Marine petroleum system of the Cretaceous postrift: Aptian-Late Cretaceous (?)}

Black shales formed during the Early Aptian and AptianAlbian oceanic anoxic events (the so-called OAE1a and OAE1b, respectively; Leckie et al. 2002) are widespread in the South Atlantic continental margin (Bray et al. 1998, Davison 1999, Jungslager 1999, Van der Spuy 2003, Adekola et al. 2012, Mello et al. 2012). These world-class source rocks were drilled by several Deep Sea Drilling Program (DSDP) boreholes, such as DSDP 361 and DSDP 364 in Cape and Angola basins, respectively (Foresman 1978). TOC values up to 15\% for DSDP 361 and 20\% for DSDP 364, and kerogen types I and II, have been reported for these Aptian shales (Foresman 1978, Bray et al. 1998, Hartwing et al. 2012; note that DSDP 361 and DSDP 364 were inadvertently exchanged by Bray et al. 1998 in their text).

The oldest postrift sequence of the Punta del Este Basin is dated as Aptian on the basis of its stratigraphic position and seismic attributes, very alike to those of the conjugate margin. It is the same seismic unit mapped by Grassmann et al. (2011). The top of the unit is marked by a reflection equivalent to the AR2 horizon of Hinz et al. (1999). Thus, black shales are expected to have been present in distal positions of the continental margin of Uruguay (i.e., far from the drilled area). In fact, these shales represent the main infill of a recently recognized pull-apart basin offshore Uruguay (Rowlands et al. 2016).

Reservoir rocks were identified in seismic data, including Cretaceous basin floor fans, slope fans, lowstand wedges and shelf-edge deltas. Reservoir quality is expected to have improved due to pirating of fine sediments by the action of strong contour currents (Creaser et al. in press). Locally, possible limestones atop basement highs were also identified as secondary reservoirs. Seal rocks include regional marine shales of Paleocene-Eocene age (Gaviotín Formation).

Given the scarcity of faults in the Cretaceous postrift sequence, hydrocarbon migration is expected to have been mainly lateral, through carrier beds and unconformities.

The oil window would have been reached in the Paleocene, oil generation peak in the Eocene and wet gas/condensate in the Eocene/Oligocene. Dry gas is expected to be generated since the Miocene.

This petroleum system has been proven not only in the South Atlantic's continental margin, with both oil fields and gas fields (e.g. Kudu field off Namibia; Bray et al. 1998). According to seismic data and geological model, its presence in the continental margin of Uruguay is highly probable. This petroleum system has the advantage of the close proximity of source and reservoir rock, which increases the probability of reservoirs to be charged. The main risk is the relatively high play depth (>2,000 m water depth and >4,000 $\mathrm{m}$ rock depth).

This speculative petroleum system is summarized in Figure 7.

\section{Marine petroleum system of the Cenozoic postrift: Paleocene-Paleogene/Neogene(?)}

The shales of the Gaviotín Formation, of PaleoceneEocene age (Daners \& Guerstein 2004), were drilled by the Gaviotín and Lobo Wells and reach TOC values of up to $1,9 \%$ (Chevron Oil Uruguay 1976). However, in the region of the wells, the low overburden precluded organic matter maturation. In the distalmost sector of the continental margin, this source rock may have reached the oil window.

Reservoir rocks include Paleogene and, perhaps, also Neogene sandstones corresponding to basin floor fans, lowstand wedges, and deltaic and shelfal deposits. Reservoir quality is inferred to have been improved due to pirating of fine sediments by the action of strong contour currents

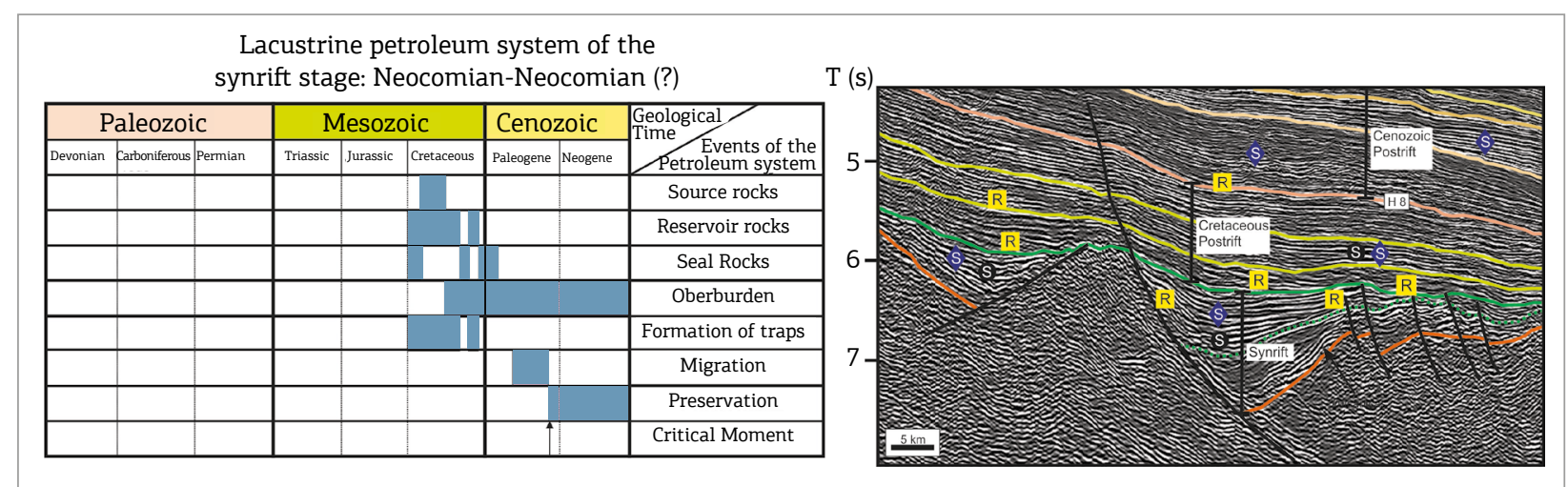

Figure 6. The lacustrine petroleum system of the synrift stage: Neocomian-Neocomian(?), showing the chart of events and a representative seismic section. $S$ in black circle: potential source rocks. $S$ in blue rhombus: potential seal rocks. $\mathrm{R}$ in yellow square: potential reservoir rocks. Seismic profile courtesy of ANCAP. 
(Hernández-Molina et al. in press). Regional seal rocks are represented by marine Paleogene and Neogene shales.

Traps would be of stratigraphic type. Given the absence of faults in the Cenozoic postrift sequence (fault-like features are interpreted as product of shale dehydration), hydrocarbon migration is expected to have been mainly lateral, through carrier beds and unconformities.

Potential source rocks would have reached oil window in the Eocene, oil generation peak in the late Eocene and wet gas/condensate window in the Oligocene. Nowadays, dry gas is probably being generated.

This petroleum system shows a high diversity of reservoir rocks, both in age (Paleocene, middle Eocene, Oligocene, Miocene) and depositional environment (see above). Eocene barchanoid dunes, sand wave fields and sand ribbons have been recently described (Hernández-Molina et al. in press), further increasing the number of reservoir types. Reservoir may have been charged not only by the Paleocene source rock, but also potentially by Cretaceous source rocks. However, the scarcity of faults in the postrift sequence and the thickness of the Cenozoic marine shales reduce the probability of reservoirs to have been charged. Another high risk is the maturity of the source rock.

This speculative petroleum system is summarized in Figure 8.

\section{CONCLUSIONS}

As in other Atlantic passive margins, four tectono-stratigraphic stages can be identified in the evolution of the Punta del Este Basin: prerift, rift, transition and postrift. Each of these stages shows a particular structural configuration and stratigraphic architecture, being relatively favorable for the development of petroleum systems.

On the basis of seismostratigraphic analysis and analogies with other South Atlantic basins, four speculative petroleum systems were proposed for the Punta del Este Basin:

marine petroleum system of the prerift stage;

- lacustrine petroleum system of the synrift stage;

marine petroleum system of the Cretaceous postrift; and marine petroleum system of the Cenozoic postrift.

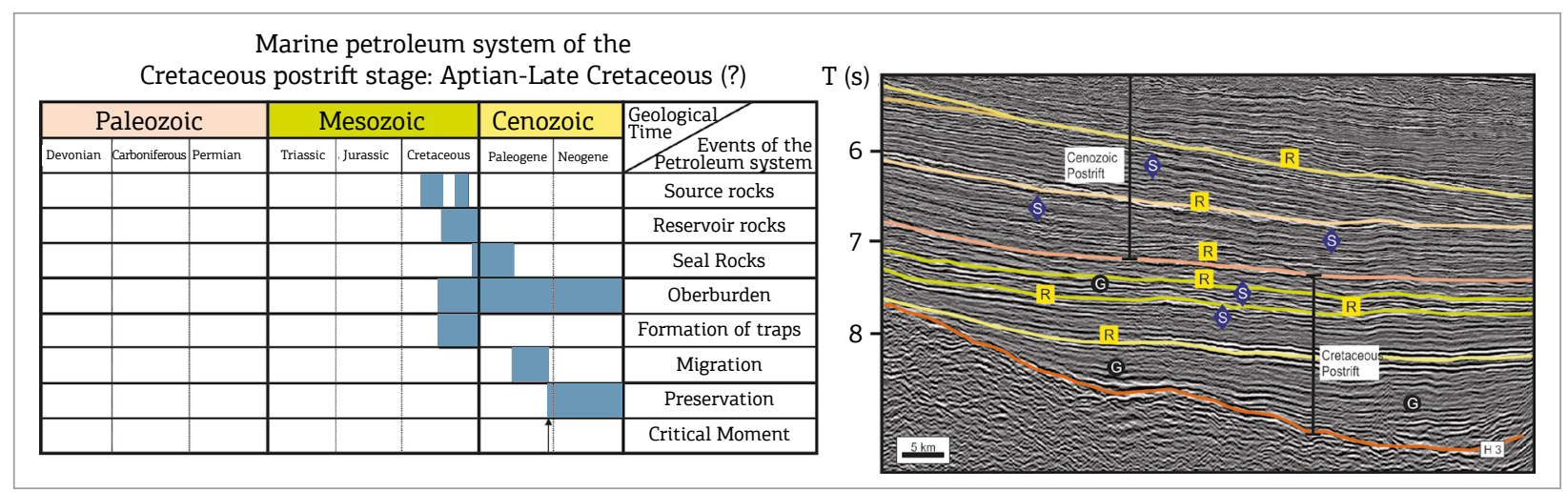

Figure 7. Marine petroleum system of the Cretaceous postrift: Aptian-Late Cretaceous(?), showing the chart of events and a representative seismic section. $S$ in black circle: potential source rocks. $S$ in blue rhombus: potential seal rocks. $\mathrm{R}$ in yellow square: potential reservoir rocks. Seismic profile courtesy of ANCAP.

\begin{tabular}{|c|c|c|c|c|c|c|}
\hline \multicolumn{7}{|c|}{$\begin{array}{l}\text { Marine petroleum system of the Cretaceous } \\
\text { postrift stage: Paleocene-Paleogene/Neogene }\end{array}$} \\
\hline \multicolumn{2}{|c|}{ Paleozoic } & \multicolumn{3}{|c|}{ Mesozoic } & \multirow{2}{*}{\begin{tabular}{|l|l|}
\multicolumn{2}{|c|}{ Cenozoic } \\
Paleogene & Neogene \\
\end{tabular}} & \multirow{2}{*}{$\begin{array}{l}\text { Geological } \\
\text { Time Events of the } \\
\text { Petroleum system }\end{array}$} \\
\hline Devonian & Carboniferous Permian & Triassic & \begin{tabular}{|l|} 
Jurassic \\
\end{tabular} & Cretaceous & & \\
\hline & & & & & & Source rocks \\
\hline & & & & & & Reservoir rocks \\
\hline & & & & & & Seal Rocks \\
\hline & & & & & & Oberburden \\
\hline & & & & & & Formation of traps \\
\hline & & & & & & Migration \\
\hline & & & & & & Preservation \\
\hline & & & & & & Critical Moment \\
\hline
\end{tabular}

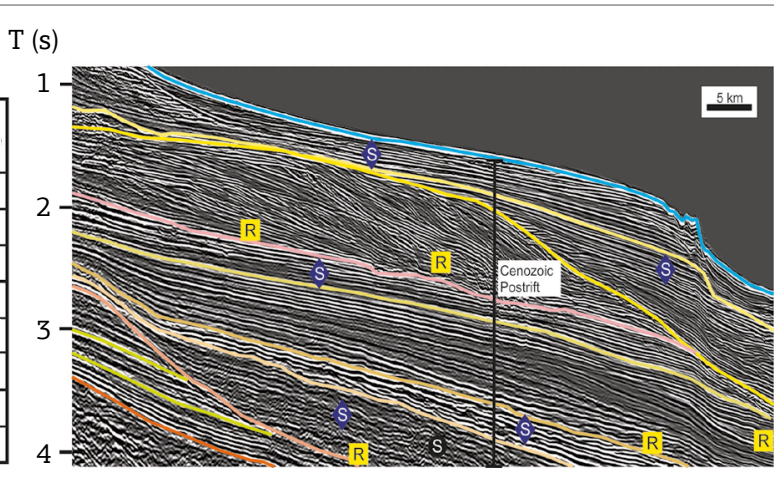

Figure 8. Marine petroleum system of the Cenozoic postrift: Paleocene-Paleogene/Neogene(?), showing the chart of events and a representative seismic section. $S$ in black circle: potential source rocks. $S$ in blue rhombus: potential seal rocks. $\mathrm{R}$ in yellow square: potential reservoir rocks. Seismic profile courtesy of ANCAP. 
Overall, the third petroleum system seems to have the largest hydrocarbon potential, due to the simultaneous occurrence of a potential, world-class marine Aptian source rock (proven in the South Atlantic and with lacustrine correlates onshore
Uruguay), widespread marine turbiditic sandstones close to the source rocks (favoring their charge), and a thick regional seal. Neither burial depth nor timing is identified as risks for this petroleum system.

\section{REFERENCES}

Adekola S.A., Akinlua A., Mangelsdorf K. 2012. Organic geochemical evaluation of Cretaceous shale samples from the Orange Basin, South Africa. Applied Geochemistry, 27(8): 1633-1642.

Becker J.J., Sandwell D.T., Smith W.H.F., Braud J., Binder B., Depner J., Fabre D., Factor J., Ingalls S., Kim S-H., Ladner R., Marks K., Nelson S., Pharaoh A., Trimmer R., Von Rosenberg J., Wallace G., Weatherall P. 2009. Global bathymetry and elevation data at 30 arc seconds resolution: SRTM30_PLUS. Marine Geodesy, 32(4):355-371.

Beglinger S.E., Doust H., Cloetingh S. 2012. Relating petroleum system and play development to basin evolution: Brazilian South Atlantic Margin. Petroleum Geoscience, 18:315-336.

Blaich O.A., Faleide J.I., Tsikalas F., Franke D., León E. 2009. Crustalscale architecture and segmentation of the Argentine margin and its conjugate off South Africa. Geophysical Journal International, 178(1):85-105.

Bray R., Lawrence S., Swart R. 1998. Source rock, maturity data indicate potential off Namibia. Oil and Gas Journal. 96(32):84-89.

Campos L., Milani E., Toledo M., Queiroz R., Catto A., Selke S. 1998. Barra Bonita: a primeira acumulação comercial de hidrocarboneto da Bacia do Paraná (Barra Bonita: The first commercial hidrocarbon accumulation of Paraná Basin). Brazilian Petroleum Institute - IBP. In: Presentantion paper in Rio \& Gas Conference. Rio de Janeiro, Brazil.

Catuneanu O. 2006. Principles of Sequence Stratigraphy. Amsterdam, Elsevier Science Ltd., 375 p.

Chang H.K., Assine M.L., Corrêa F.S., Tinen J.S., Vidal A.C., Koike L. 2008. Sistemas petrolíferos e modelos de acumulação de hidrocarbonetos na Bacia de Santos. Revista Brasileira de Geociências, 38(2-Suplemento):29-46.

Chang H.K., Kowsmann R.O., Figueiredo A.M.F., Bender A.A. 1992. Tectonics and stratigraphy of the East Brazil Rift system: An overview. Tectonophysics, 213:97-138.

Chevron Oil Uruguay. 1976. Biostratigraphy of the Lobo and Gaviotín Wells - Offshore Uruguay. Resumo. 1p. Internal report.

Conti B., Perinotto J.A.J., Veroslavsky G., Castillo M.G., de Santa Ana H., Soto M., Morales E. 2017. Speculative petroleum systems of the southern Pelotas Basin, offshore Uruguay. Marine and Petroleum Geology, 83:1-25.

Coward M.P., Purdy E.G. Ries A.C., Smith D.G. 1999. The distribution of the petroleum reserves in basins of the South Atlantic margin. In: Cameron M.R., Bate R.H., Clure V.S. (eds) The oil and gas habitats of the South Atlantic. Geological Society, London, Special Publications, 153:101-131.

Creaser A., Hernández-Molina F. J., Badalini G., Thompson P., Walker R., Soto M., Conti B. in press. A late Cretaceous mixed (downand along-slope) depositional system on the Uruguayan Margin: Sedimentary and palaeoceanographic significance. Marine Geology.

Daners G. \& Guerstein G.R. 2004. Dinoflagelados del MaastrichtienesePaleogeno en la Formación Gaviotín, cuenca Punta del Este. In: Veroslavsky G., Ubilla M., Martínez S. (eds.) Cuencas sedimentarias de Uruguay; Geología, Paleontología y Recursos Naturales, Cenozoico. Edición: División Relaciones y Actividades Culturales de Facultad de Ciencias, Montevideo. p. 37-62.
Davison I. 1999. Tectonics and hydrocarbon distribution along the Brazilian South Atlantic margin. In: Cameron M.R., Bate R.H., Clure V.S. (eds) The oil and gas habitats of the South Atlantic. Geological Society, London, Special Publications, 153:133-151.

de Santa Ana H.. 2000. Formación Mangrullo (Cuenca Norte, Uruguay) - estratigrafía y recursos minerales asociados. Revista de la Sociedad Uruguaya de Geología, 7:2-14.

de Santa Ana, H., \& Ucha, N. 1994. Exploratory potential of the Uruguayan sedimentary basins. ANCAP. Internal report. 155p.

Figueroa D., Marshall P., Prayitno W. 2005. Cuencas atlánticas de aguas profundas: principales plays. In: Chebli G., Cortiñas J., Spalletti L., Legarreta L., Vallejo E. (eds.) Frontera Exploratoria de la Argentina. In: VI Congreso de Exploración y Desarrollo de Hidrocarburos. Mar del Plata, Argentina, p. 325-335.

Foresman J. 1978. Organic Geochemistry DSDP LEG 40, Continental Rise of Southwest Africa. Available at: http://www.deepseadrilling. org/40 [cited at Oct. 2017]

Franke D., Neben S., Ladage S., Schreckenberger B., Hinz K. 2007. Margin segmentation and volcano-tectonic architecture along the volcanic margin off Argentina/Uruguay, South Atlantic. Marine Geology, 244(1-4):46-67.

Gladczenko T.P., Hinz K., Eldholm O., Meyer H., Neben S., Skogseid J. 1997. South Atlantic volcanic margins. Journal of the Geological Society, 154:465-470.

Grassmann S., Franke D., Neben S., Schnabel M., Damm V. 2011. Maturity modelling of the deepwater continental margin, offshore Argentina. Zeitschrift der Deutschen Gesellschaft für Geowissenschaften, 162(1):79-89.

Hartwing A., di Primio R., Anka Z., Horsfield B. 2012. Source rock characteristics and compositional kinetic models of Cretaceous organic rich black shales offshore southwestern Africa. Organic Geochemistry, 51:17-34

Heine C., Zoethout J., Müller R.D. 2013. Kinematics of the South Atlantic rift. Solid Earth, 4:215-253.

Hernández-Molina F. J., Campbell S., Badalini G., Thompson P., Walker R., Soto M., Conti B., Creaser A., Preu B., Thieblemont A., Hyslop L., Morales E. in press. Large bedforms on contourite terraces: sedimentary and conceptual implications. Marine Geology.

Hinz K., Neben S., Schreckenberger B., Roeser H.A., Block M. Gonçalvez de Souza K., Meyer H. 1999. The Argentine continental margin north of $48^{\circ} \mathrm{S}$ : Sedimentary successions, volcanic activity during breakup. Marine and Petroleum Geology, 16(1):1-25.

Holz M. Kalkreuth W., Rolim S.B.A. 2010. Extension of the Paraná Basin to offshore Brazil: Implications for coalbed methane evaluation. Marine and Petroleum Geology, 27:1119-1132.

Introcaso \& Ramos. 1984. La cuenca del Salado: un modelo de evolución aulacogénica. In: IX Congreso Geológico Argentino y III Congreso de Exploración de Hidrocarburos. Buenos Aires, Argentina.

Jungslager E.H.A. 1999. Petroleum habitats of the South Atlantic margin. In: Cameron N. R., Bate R. H., Clure V. S. (eds) The Oil and Gas Habitats of the South Atlantic. Geological Society of London, Special Publications, 153:153-168. 
Leckie R.M., Bralower T.J., Cashman R. 2002. Oceanic anoxic events and plankton evolution: Biotic response to tectonic forcing during the mid-Cretaceous. Paleoceanography, 17(3). doi: 10.1029/2001PA000623.

MacDonald D., Gomez-Perez I., Franzese J., Spalletti L., Lawver L., Gahagan L., Dalziel I., Thomas C., Trewin N., Hole M., Paton D. 2003. Mesozoic break-up of SW Gondwana: Implications for regional hydrocarbon potential of the southern South Atlantic. Marine Petroleum Geology, 20(3-4):287-308.

Magoon L. \& Dow W. 1994. The Petroleum System. In: Magoon L. \& Dow W. (eds.) The petroleum system - from source to trap. Chapter 1 , p. 3-24. AAPG Memoir 60.

Mello M.R., Azambuja Filho N.C., Bender A.A., Barbanti S.M., Mohriak W., Schmitt P., Jesus C.L.C. 2012. The Namibian and Brazilian southern South Atlantic petroleum systems: are they comparable analogues? Geological Society, London, Special Publications, 369. doi: 10.1144/SP369.18

Mello M.R., Mohriak W., Koutsoukos E.A.M., Bacoccoli G. 1994. Selected petroleum system in Brazil. In: Magoon L.B. \& Dow W.G. (eds) The Petroleum System - from Source to Trap. American Association of Petroleum Geologists Memoirs, 60:499-512.

Milani E.J, Brandão J.A.S.L., Zalán P.V., Gamboa L.A.P. 2000. Petróleo na margem continental brasileira: Geologia, exploração, resultados e perspectivas. Revista Brasileira de Geofísica, 18(3):352-396.

Milani E.J., Thomaz Filho A. 2000. Sedimentary Basins of South America. In: Cordani U.G., Milani E.J., ThomazFilho A., Campos D.A. Tectonic Evolution of South America. Edição Especial do 31st International Geological Congress, p. 389-449.

Milani E.J. \& Zalán P.V. 1999. An outline of the geology and petroleum systems of the Paleozoic interior basins of South America. Episodes, 22(3):199-205

Morales E. 2013. Evolução tectônica e estratigráfica das bacias da margem continental do Uruguai. PhD Thesis, Universidade Estadual Paulista Júlio de Mesquita Filho, Campus Rio Claro.

Morales E., Chang H. K., Soto M., Corrêa F.S., Veroslavsky G., de Santa Ana H., Conti B., Daners G. 2017. Tectonic and stratigraphic evolution of the Punta del Este and Pelotas basins (offshore Uruguay). Petroleum Geoscience, 23(3). doi: 10.1144/ petgeo2016-059.

Moulin M., Aslanian D., Olivet J-L., Contrucci I., Matias L., Géli L., Klingelhoefer F., Nouzé H., Réhault J., Unternehr P. 2005. Geological constraints on the evolution of the Angolan margin based on reflection and refraction seismic data (ZaïAngo Project). Geophysical Journal International, 162(3):793-810.

Pángaro F. \& Ramos V.A. 2012. Paleozoic crustal blocks of onshore and offshore central Argentina: New pieces of the southwestern Gondwana collage and their role in the accretion of Patagonia and the evolution of Mesozoic south Atlantic sedimentary basins. Marine and Petroleum Geology, 37(1):162-183.

Pángaro F., Ramos V.A., Pazos P.J. 2015. The Hesperides basin: A continental-scale upper Palaeozoic to Triassic basin in southern Gondwana. Basin Research. 28(5):685-711. doi: 10.1111/bre.12126.

Pollack H.N., Hurter S.J., Johnson J.R. 1993 Heat flow from the Earth's interior: Analysis of the global data set. Reviews of Geophysics, 31(3):267-280. doi: 10.1029/93RG01249.

Rabinowitz P.D. \& LaBrecque J. 1979. The Mesozoic South Atlantic Ocean and evolution of its continental margins. Journal of Geophysical Research, 84(B11):5973-6002.
Raggio F., Gerster R., Welsink H. 2011. Cuencas del Salado y Punta del Este. In: VIII Congreso de Exploración y Desarrollo de Hidrocarburos. Simposio Cuencas Argentinas: visión actual. Mar del Plata. Argentina. CD-ROM.

Rossello E., de Santa Ana H., Veroslavsky G. 2000. El lineamiento Santa Lucía-Aiguá-Merín (Uruguay): un corredor tectónico extensivo y transcurrente dextral precursor de la apertura Atlántica. Revista Brasileira de Geociências, 30(4):749-756.

RosselloE.A., Veroslavsky G., Masquelin H., Santa Ana H. 2007. El corredor tectónico juro-cretácico Santa Lucía-Aiguá-Merín (Uruguay): evidencias cinemática transcurrentes dextrales y controles preexistentes. Revista de la Asociación Geológica Argentina. 62(1):92-104.

Rowlands H.J., Paton D., Turner J.P., Thompson P. 2016. The Influence of Basement Structure and Volcanics on the Evolution of the Uruguayan Margin. Abstract 2099767: Bulletin American Association of Petroleum Geologists In: AAPG Annual Convention and Exhibition, Denver, CO

Soto M., Morales E., Veroslavsky G., Santa Ana H., Ucha N., Rodríguez P. 2011. The continental margin of Uruguay: Crustal architecture and segmentation. Marine and Petroleum Geology, 28(9):1676-1689.

Stoakes F.A., Campbell C.V., Cass R., Ucha N. 1991. Seismic stratigraphic analysis of the Punta del Este Basin, offshore Uruguay, South America. Bulletin American Association of Petroleum Geologists, 75(2):219-240.

Tankard A.J., Uliana M.A., Welsink H.J., Ramos V.A., Turic M., Franca A.B., Milani E.J., De Brito Neves B.B., Eyles N., Skarmeta J., Santa Ana H., Wiens F., Ciribian M., Lopez P.O., Germs G.J.B., De UIT M.J., Machacha T., Miller R. McG. 1995. Structural and tectonic contros of basin evolution in southwestern Gondwana during the Phenerozoic. In: Tankard A.J., Suárez Soruco R., Welsink H.J. (eds.) Petroleum basins of South America. American Association of Petroleum Geologists, 62:5-52

Tavella G.F. \& Wright C.G. 1996. Cuenca del Salado. In: Ramos V.A. \& Turic M.A. (eds) Geología y Recursos Naturales de la Plataforma Continental Argentina., 6:95-116.

Ucha N., de Santa Ana H., Veroslavsky G. 2004. La Cuenca Punta del Este: geología y potencial hidrocarburífero. p. 173-192. In: Veroslavsky G., Ubilla M., Martínez S. (eds.) Cuencas Sedimentarias de Uruguay: Geología, Paleontología y recursos naturales - Mesozoico. DIRAC, Montevideo.

Urien C.M. 2001. Present and future petroleum provinces of southern South America. p. 373-402. In: Downey M.W., Threet J.C., Morgan W.A. (eds.) Petroleum Provinces of the Twenty-First Century. American Association of Petroleum Geologists. Memoir 74.

Van der Spuy D. 2003. Aptian source rocks in some South African Cretaceous basins. In: Arthur T.J., MacGregor D.S., Cameron N.R. (eds) Petroleum Geology of Africa: new themes and developing technologies. Geological Society of London Special Publications, 207:185-202.

Veroslavsky G., Daners G., de Santa Ana H. 2003. Rocas sedimentarias pérmicas de la plataforma continental uruguaya: el prerift de la Cuenca de Punta del Este. Sociedade Geológica de España, 34:203-206.

Veroslavsky G., Rossello E.A., Muzio R., de Santa Ana H. 2007. Tectónica y magamatismo de la Cuenca Laguna Merin: relictos de una proto dorsal oceánica jurocretácica. In: V Congreso Uruguayo de Geología. Montevideo. Resúmenes. CD-ROM.

Available at www.sbgeo.org.br 